\title{
FLEXIBLE WORKING IN SCOTTISH LOCAL AUTHORITY PROPERTY: DEVELOPING A COMBINED RESOURCE MANAGEMENT STRATEGY
}

\author{
Thadsin KHAMKANYA ${ }^{1}$ and Brian SLOAN $2 \bowtie$ \\ 1 School of Engineering and the Built Environment, Napier University, 10 Colinton Road, \\ Edinburgh, Scotland EH10 5DT, UK \\ E-mail: t.khamkanya@napier.ac.uk \\ 2 School of Engineering and the Built Environment, Napier University, 10 Colinton Road, \\ Edinburgh, Scotland EH10 5DT, UK \\ E-mail:B.Sloan@napier.ac.uk
}

Received 31 March 2008; accepted 12 June 2008

\begin{abstract}
As indicated in Government reports and previous research, the traditional office environment of both central and local governments has been occupied with high occupancy cost. Flexible working supported by information and communication technology, human resource, and workspace management has emerged as a modern concept for managing office resources. Workspace management models covering both activity-based working area and portfolio flexibility are developed to assist an organisation to allocate staff and working area more flexibly and efficiently. However, public organisations like Scottish Local Authorities (SLAs) are unlikely to fully adopt commercial workspace management models. Therefore, the concept of a combined resource management strategy has been introduced to assist the Authorities in considering adoption in financial/economic terms before taking-up of flexible working in practice.
\end{abstract}

KEYWORDS: Flexible working; Combined resource management strategy; Scottish local authority

\section{INTRODUCTION}

Property management principles in the public sector have been continuously developed by researchers and practitioners over the last two decades. The need for more effective, efficient, and economic use of property has been recommended by UK Government reports such as Audit Commission (2000) Hot Property Report, Gershon (2004) - Public Sector Efficiency Review, and Lyons' Reviews $(2004 a, b)$. The reports address the term 'Flexible Working' (FW) as a modern concept that should be applied to public organisations. The emergence of the flexibility principle is likely to influence property management practice, in terms of operational flexibility and efficiency. This paper aims to describe an application of flexible working, especially Workspace Management (WSM) in public organisation offices. Moreover, the implications from the survey of flexible working in Scottish Local Authority (SLA) property are described to assist public offices, like SLA, to successfully take-up flexible working in this context. 


\section{LITERATURE REVIEW}

\subsection{Needs for flexible working}

Efficiency, Effectiveness and Economics (3Es) in property management have been recommended by both researchers and, particularly, Government auditors. Audit Commission (AC) (1988a, 1988b) recommends property management of Local Authorities (LAs) to prepare strategic operational cost information and adequate property review. The main reason given is that strategic property management information, such as income, expenses and occupancy costs per area, can enable senior management to achieve better efficiency, effectiveness and economy of property management (Gibson and Hedley, 1999). Moreover, Audit Commission (2000) indicates key actions for property review of LAs, including regular reviews of utilisation of property holdings and sharing of back offices, where $3 \mathrm{Es}$ can be gained. Consequently, office management and Human Resource (HR) concepts, such as openplan, hotdesking, electronic communication and flexible working hours, have been introduced to LAs as modern property management tools (ibid). Lyons (2004a) stated that because Information and Communication Technology (ICT) has been significantly developed, the office environment can be changed from a static to a flexible working environment. He suggests that the three key areas which should be considered are property efficiency, productivity and service effectiveness, and regional economic growth and devolution. In his opinion, when these three areas are improved, the office estate can be managed more strategically.

Gershon (2004) and Lyons (2004b) identify the broad objectives of public sector efficiency. These are: 1) reduce resource costs, not public services; 2) enhance quality and quantity of production; and 3) improve ratio of output per unit cost of input. To achieve these objectives, LAs should:

- Increase the level of investment in ICT in both central and local government,

- Develop a HR joined-up approach facilitating back office functions, and

- Share back offices both within and between LAs.

To indicate the importance of operational efficiency, the Office of Government Commerce (OGC) and Investment Property Databank (IPD) (2005a,b) undertook a property occupational-performance survey across the UK. A quadrant analysis of the survey (Figure 1) clearly shows that only nine per cent of pilot-survey offices can be counted as efficient occupation. Fifty-two per cent (i.e. $15+37 \%$ ) need to improve the efficiency of property oc-

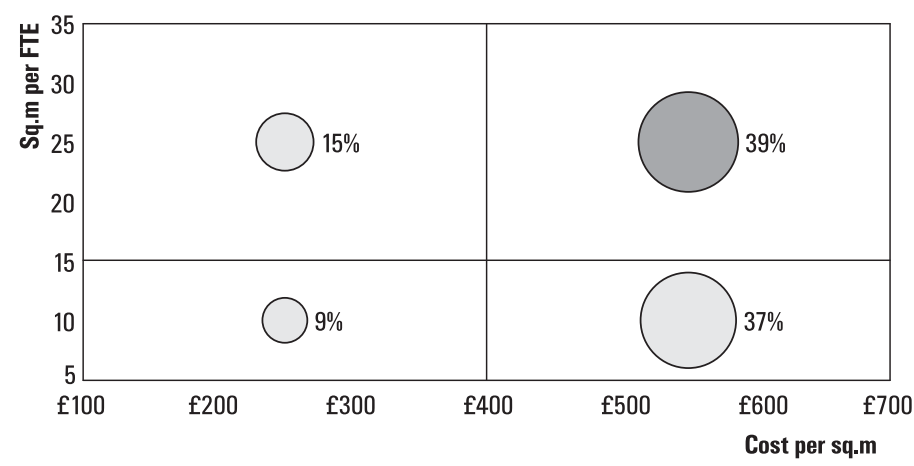

Figure 1. Occupancy cost per area and workspace density in public offices by quadrant Source: OGC and IPD (2005a) 
cupation, either the working area density or occupancy cost. Interestingly, thirty-nine per cent of the pilot samples cannot be identified as efficient occupational property (OGC and IPD, 2005a,b).

Efficient performance recommendations, established as the survey outcome, for property occupation are (OGC and IPD, 2005a,b):

1. Maximum density of office space should not be exceeded at 15 sq. m. per Full-Time Equivalent (FTE).

2. Ratio of staff per workstation should not exceed 1:1.

3. Occupancy cost per area should not exceed $£ 400$ per sq. m.

If these targets can be achieved, theoretically, the potential saving of around 25 per cent of current annual occupancy cost will be achieved (OGC, 2006).

The issues addressed above show that senior management should consider employing the modern concept of office management, especially flexible working, as a tool for achieving better 3Es of property management (Gibson and Luck, 2004). To understand the relationship between flexible working and property management, flexibility principle and workspace management concepts are described as fundamental principles for managing office area more effectively.

\subsection{Flexibility principle}

The principle of flexibility has been addressed by Gibson (2003) as a key concept for flexible working. There are two perspectives on flexibility, which relate to the organisation and property.

\subsubsection{Flexibility from an organisation perspective}

Organisations always expect to increase their resources performance, while workers expect more suitable working condition (ibid). There are three important types of organisation flexibility which are:

\section{Contractual Flexibility}

Full-time and non full-time (e.g. part-time or short-term) staff can be employed on a portfolio flexibility basis (Gibson and Lizieri, 1999). Full-time staff will work in core office areas, whereas the peripheral staff are employed depending on organisational needs to fulfil organisation business (Gibson, 2003).

\section{Time Flexibility}

Work-Life Balance is a main principle of time flexibility. Organisations may provide ranges of working-time flexibility patterns to their employees in terms of: alternative working time, alternative working place, and additional benefits (Gibson, 2003; DfEE, 2000).

\section{Locational Flexibility}

In a modern office, employees should be able to choose their workplaces based on working activities. For example, if a worker needs to do a concentrated task, he/she should be provided a personal office for the period of the task (Laing et al., 1998; Ward and Holtham, 2000).

\subsubsection{Flexibility from a property perspective}

According to organisational business pressure, awareness of liability associated with property, frequent relocation of staff, productivity improvement, and total occupancy cost are counted as important factors leading an organisation to adapt the flexibility concept (Gibson, 2003; NAO, 2006a). Three main types of property flexibility are:

\section{Contractual (Financial) Flexibility}

According to the property portfolio model, organisations should monitor and manage their property assets both freehold and leasehold based on the business utilisation purpose (Gibson and Lizieri, 1999). For example, shortterm property may be arranged in order to facilitate a quick disposal.

\section{Physical Flexibility}

Working space in the office should be easily adapted when business activity changes. The 
office should provide flexibility to change its layout, for example, from cellular office to open plan office (Laing et al., 1998; Gibson, 2003)

\section{Functional Flexibility}

Organisations should provide flexibility for changing business functions. This relates to the office location, and legal and planning obligations (Gibson, 2003).

Flexible working requires flexibility from the organisation and property perspectives supporting its adoption in practice. Moreover, senior management have an important role in promoting flexible working in their business. Therefore, the opportunities for improving performance and reducing occupancy cost may be considerably increased (Simms and Rogers, 2006).

\subsection{Workspace management}

Impacts of modern ICT (broadband, wireless, etc.) and management concepts (hotdesking, flexitime working hours, etc.) influence working styles of people from a static to a dynamic style (Dettwiler, 2008). Much office workspace has been changed from a traditional layout (arranged by group of functions) to a modern layout (arranged by activity objective) (McGregor, 2000). Current workspace management concepts include work-space and portfolio flexibility models.

\subsubsection{Workspace models}

Working activities should be supported by suitable working environments. To understand classification of workspace, two developed models could be used. First, the 'work patterns and space' model, a two-dimensional matrix, presents the relationship between interaction and autonomy (Figure 2).

Four major work environments are (Laing et al., 1998; Nenonen, 2004; Szarejko and Trocka-Leszczynska, 2007):

Hive suits routine work which does not require confidentiality or concentration.

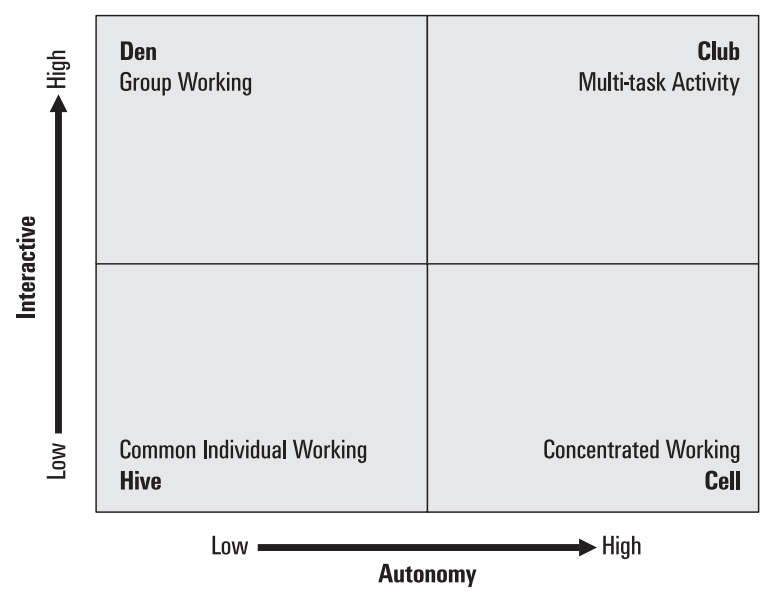

Figure 2. Work patterns and space model Adapted from: Laing et al. (1998)

Cell suits specific work which requires concentration and confidentiality.

Den suits simple teamworking activities or collaborative activities.

$\boldsymbol{C l u b}$ suits complex and multi-task works which require high level of transaction, and mutual interactions.

Second, as shown in Figure 3, the 'knowledge-mind workspace' model presents the relationship between knowledge work and minded space (Ward and Holtham, 2000).

The horizontal axis of the model presents a level of minded space where single-minded space is a space for a single function and open-minded space is used for multifunctional or participative working activities. The vertical axis presents a degree of knowledge work which ranges from individual to collaborative level. Individual knowledge work requires a particular knowledge of a person who performs one task. Whereas, collaborative knowledge work needs interactive ideas from many people performing one or more tasks (ibid).

\subsubsection{Portfolio flexibility}

The concept of portfolio flexibility has been developed by Gibson and Lizieri (1999) for supporting flexible use of commercial workspace. 


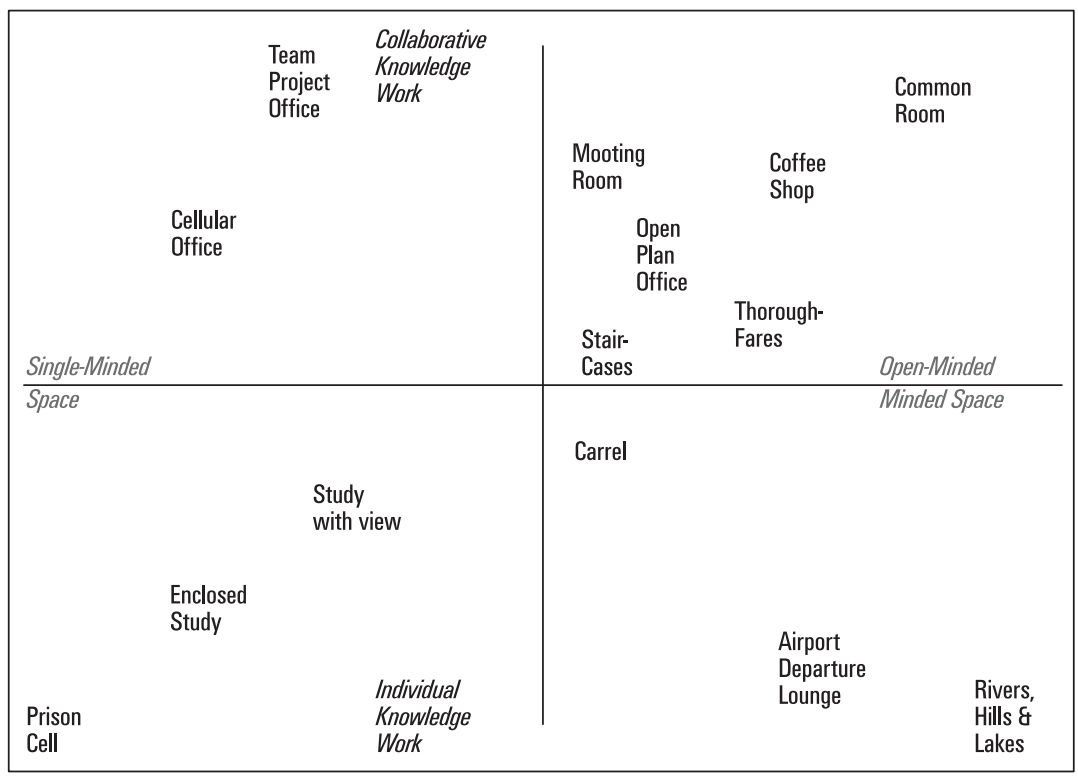

Figure 3. Knowledge-mind workspace Source: Ward and Holthem (2000)

Portfolio flexibility provides ranges of property or workspace use for organisations that have different utilisation objectives (Gibson and Lizieri, 2000)

As shown in Figure 4, flexibility of each peripheral area is categorised by utilisation purpose (Gibson and Lizieri, 1999; Gibson and Lizieri, 2000; Gibson, 2000). Core periphery is an area used for long-term purposes. Long-termcontract staff usually work in this area. For the first peripheral portfolio - an organisation generally uses this for supporting its business requirement in the short-term. Short-term lease or license is required for occupying this area and the occupying organisation should be able to exit at any time. The second periphery portfolio is typically used for very short-term periods. For example, this area is suitable for training and organising very short-term events and use as a temporary office.

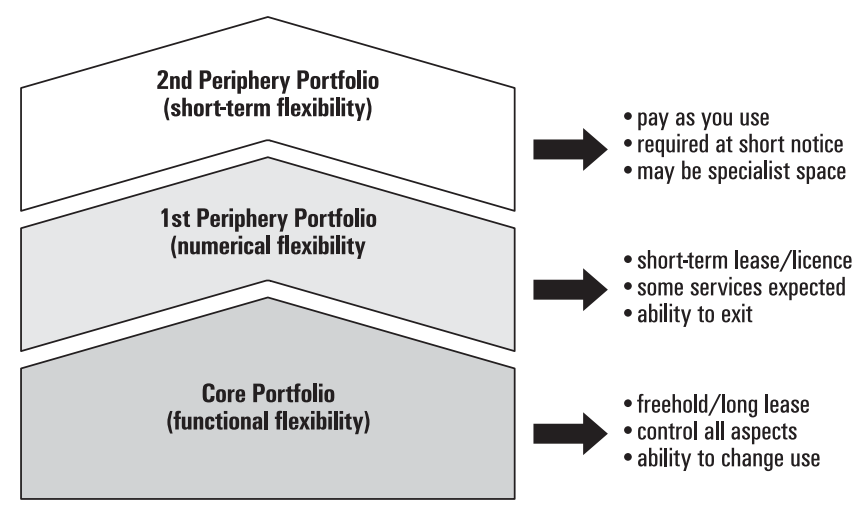

Figure 4. Corporate property portfolio Source: Gibson (2000) 


\subsubsection{Combination of workspace- portfolio flexibility models}

The workspace models and the portfolio flexibility models can be merged in order to increase the degree of flexibility of workspace management models (Figure 5). As influenced by the workspace models, working areas can be arranged into four major types, which are hive, cell, den, and club in order to support staff activities. The portfolio flexibility model enables the organisation to categorise its workspaces into three flexible utilisation levels which are core, first, and second peripheries. Combining the two models (Figure 5) gives a different perspective on flexibility.

Therefore, when the organisation can arrange its workspace, based on the combination of these models, it may achieve the higher level of $3 \mathrm{Es}$, in particular:

- Staff can perform the right activities in the right areas, based on work-space concepts (Laing et al., 1998; Ward and Holthem, 2000). Consequently, overall working performance and staff satisfaction are likely to be higher;

- When the organisation can arrange flexibility peripheries of its office area, some working areas may be able to be let in short- or very short-term (Gibson and Lizieri, 1999; Gibson, 2000). Therefore, most working areas will be properly operated by internal and external people. This is likely to promote the higher level of financial flexibility.

\subsection{Scottish local authority - flexible working}

The adoption of flexible working has been discussed as a suitable concept for managing the modern office environment (NAO, 2006a). The benefits of adopting flexible working appear in several organisations. For example, occupancy costs have been reduced, and working atmosphere has been improved (ibid). Although organisations adopting flexible working may receive positive outcomes, the success of flexible

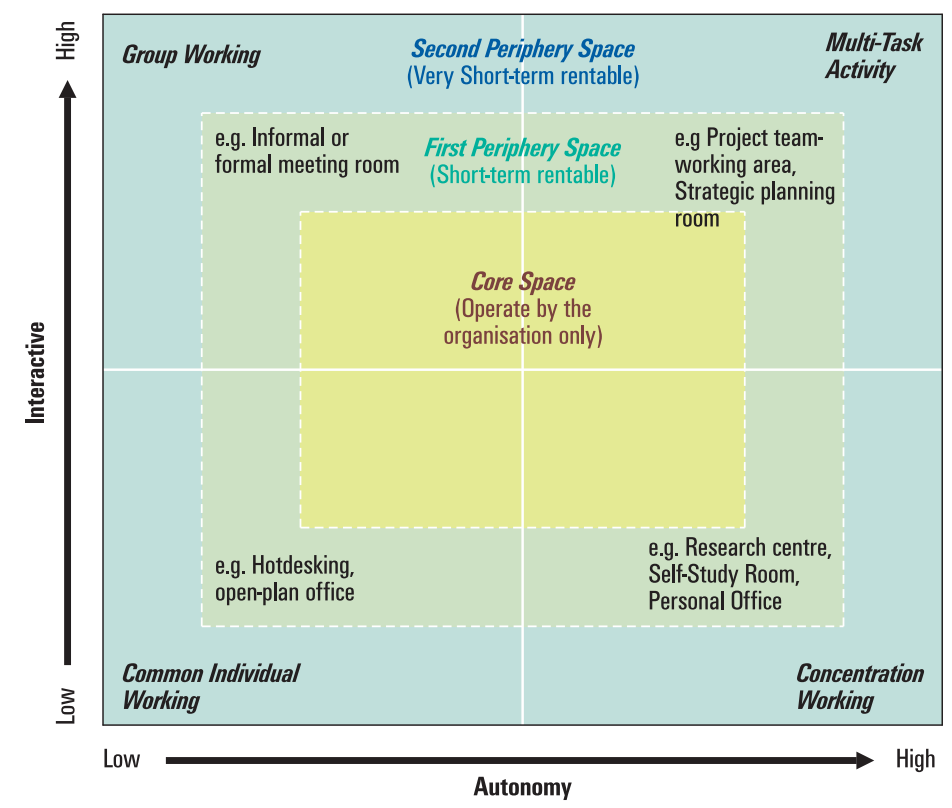

Figure 5. Combination of workspace-portfolio flexibility models Adapted from: Laing et al. (1998), Gibson and Lizieri (1999) and Ward and Holtham (2000) 
working adoption in one organisation cannot guarantee that other followers will obtain the same results. Scottish Local Authority (SLA) is an organisation having unique characteristics regarding its management system, including ICT, HR, and workspace management. Consequently, the working environment of SLAs may vary from place to place and by size. To understand the characteristics of flexible working, especially workspace management strategy in SLAs, workspace should be evaluated in terms of its arrangement and flexibility (Laing et al., 1998; Ward and Holthem, 2000; Gibson and Lizieri, 1997; Gibson, 2000). This present research aims to find out some implications of the current property management practice in SLAs and provide some recommendations for achieving the higher benefits of flexible working.

\section{RESEARCH METHODOLOGY}

The research has as its main question to understand flexible working practice in Scottish Local Authorities (SLAs). In particular:

- How does flexible working impact SLAs, in terms of operational efficiency?

- How can SLAs effectively move on to the higher flexible-working environment?

Objectives of this research are:

- To investigate the current workspace management practice of SLAs;

- To find out implications of working-area proportion of SLAs;

- To propose a suitable route for taking up of flexible working, supported by current workspace management concept, in the SLAs.

The research aims to acquire information from middle management working in ICT, $\mathrm{HR}$, and property/estate/facility management of SLAs. The invited participants are experienced staff who would be able to respond to the specific research questions in depth from their broad experience. These include, for example, property manager, senior estate officer, facility manager, ICT manager, personnel manager, and human resource management manager. The selected participants were expected to reflect the current SLA's policy direction and demands of subordinates regarding the flexibleworking environment (Bryman, 2004).

Since SLAs are scattered throughout Scotland, a postal questionnaire survey was selected as the most suitable survey method for the research (Fink, 2006). In the questionnaire, there are a number of structured questions. Data from the structured questions was used in numerical and categorical analysis and interpretation (Dawson, 2006).

After the questionnaire was prepared, a pilot test was undertaken with the City of Edinburgh Council staff. After the pilot test was completed, there were some amendments, particularly inappropriate language, difficult questions, unclear statements, too-many ranking choices, and vague wording. After the pilot test and questionnaire amendment, the size of the survey instrument was significantly reduced (by 25 per cent from the original). Benefits of pilot testing and questionnaire amendment include reducing vague questions, adjusting questionnaire structure, reducing difficulty of questionnaire and increasing the applicability of the questionnaire (Dillman et al., 2002).

According to the preliminary interview during the pilot test, some management staff were of the opinion that the flexible working concept may be poorly understood as the modern concept of property management of SLAs, because flexible working is currently promoted as a tool for only HR. Therefore, to maximise the number of responses regarding this concern, the research employs the best practice of questionnaire survey. These include advance warning of the survey request, incentivisation of survey participation, proper cooperation during the survey period, and adequate and proper follow-ups (Dillman et al., 2002; Dillman, 2000). According to this, the invitation letter and the survey information were sent to 
inform invited participants prior to the survey material being sent out. Follow-up emails with electronic questionnaires were sent to non-responded participants 4 weeks after the questionnaire had originally been sent out. After the first follow-up, further e-mails were sent out after 2 weeks and follow-up letters were sent again to non-responding participants. Some questionnaires were resent to selected participants. The response collection period finished eight weeks after the first questionnaire had been sent.

\section{SURVEY RESULT}

Out of 100 invited participants, 21\% of participants returned completed questionnaires. $8 \%$ of respondents sent back blank questionnaires and letter informing they could not respond to the survey because, for example, they did not have specific information or experience regarding flexible working practice in their SLAs. The survey results are presented as follows.

\subsection{Number of head-offices}

Table 1 presents information on the 'number of head-offices' of respondents. Of total respondents, approximately 52\% work in SLAs which have more than five head office premises, $24 \%$ work in SLAs having between 2 and 4 head offices, while a further $24 \%$ of respondents work in SLAs which have a single head-office.

\subsection{Working hours in different working areas}

Table 2 presents the data on working hours in different areas of SLAs' offices. There are six different working areas to be focused on which are individual or personal office, openplan, informal meeting, formal meeting, team working, and outside office areas.

Approximately, $34 \%$ of time is spent in an individual or personal office. $25 \%$ of working time is spent in an open-plan area. $15 \%$ of working time is spent in team working room. $6 \%$ of working time is spent in an informal meeting room. $12 \%$ of working time is spent in formal meeting room and $8 \%$ of working time is spent in an outside office situation. In the analysis section, this information will be used to discuss the implications of working time spent in different areas, including a suitable desk allocation ratio for SLAs.

\subsection{Percentage of different working area}

The current survey collected information on the percentage of different workspace types of traditional layout and modern layout offices for

Table 1. Number of head offices

\begin{tabular}{|c|c|c|c|c|c|c|c|c|}
\hline \multirow{3}{*}{$\begin{array}{l}\text { No. of } \\
\text { head } \\
\text { office } \\
\text { premises }\end{array}$} & \multicolumn{6}{|c|}{ Respondents by management area } & \multirow{2}{*}{\multicolumn{2}{|c|}{ Total respondents }} \\
\hline & \multicolumn{2}{|c|}{ Property/Asset/Estate } & \multicolumn{2}{|l|}{ ICT } & \multicolumn{2}{|c|}{ Human resource } & & \\
\hline & Count & $\%$ & Count & $\%$ & Count & $\%$ & Count & $\%$ \\
\hline 1 & & & 3 & $33.3 \%$ & 2 & $28.6 \%$ & 5 & $23.8 \%$ \\
\hline 2 & 1 & $20.0 \%$ & & & 1 & $14.3 \%$ & 2 & $9.5 \%$ \\
\hline 3 & & & 1 & $11.1 \%$ & 1 & $14.3 \%$ & 2 & $9.5 \%$ \\
\hline 4 & & & & & 1 & $14.3 \%$ & 1 & $4.7 \%$ \\
\hline $5+$ & 4 & $80.0 \%$ & 5 & $55.6 \%$ & 2 & $28.6 \%$ & 11 & $52.3 \%$ \\
\hline Total & 5 & $100.0 \%$ & 9 & $100.0 \%$ & 7 & $100.0 \%$ & 21 & $100.0 \%$ \\
\hline
\end{tabular}


Table 2. Working hours in different working area

\begin{tabular}{|c|c|c|c|c|c|c|c|c|}
\hline & & $\begin{array}{l}\text { Individual } \\
\text { or personal } \\
\text { office }\end{array}$ & $\begin{array}{l}\text { open-plan } \\
\text { area }\end{array}$ & $\begin{array}{l}\text { informal } \\
\text { meeting }\end{array}$ & $\begin{array}{l}\text { formal } \\
\text { meeting }\end{array}$ & $\begin{array}{l}\text { team } \\
\text { working } \\
\text { room }\end{array}$ & $\begin{array}{l}\text { outside } \\
\text { office }\end{array}$ & Remark \\
\hline \multirow[t]{2}{*}{$\mathrm{N}$} & Valid & 19 & 19 & 19 & 19 & 19 & 19 & \\
\hline & Missing & 2 & 2 & 2 & 2 & 2 & 2 & \\
\hline \multicolumn{2}{|c|}{ Mean } & 33.6 & 24.5 & 6.3 & 12.4 & 15.0 & 8.2 & Total 100.0 \\
\hline \multicolumn{2}{|c|}{ Median } & 45.0 & 0 & 5.0 & 10.0 & 5.0 & 5.0 & \\
\hline \multicolumn{2}{|c|}{ Mode } & 0 & .0 & .0 & 10.0 & .0 & $.0(\mathrm{a})$ & \\
\hline \multicolumn{2}{|c|}{ Std. Deviation } & 33.7 & 32.3 & 6.6 & 7.3 & 26.3 & 9.6 & \\
\hline \multicolumn{2}{|c|}{ Range } & 90.0 & 80.0 & 20.0 & 25.0 & 90.0 & 40.0 & \\
\hline
\end{tabular}

(a) Multiple modes exist. The smallest value is shown

comparison and to provide some observations on current workspace management practice. Further analysis of the current survey reveals that, in the traditional layout office, approximately, 54\% of head-office working area is an open-plan area. $34 \%$ is individual or personal office area. $9 \%$ is a formal or informal meeting room. Only $3 \%$ of all working area is a team working area. However, in the modern layout office, $90 \%$ of head-office working area is an open-plan area. $3 \%$ is a formal or informal meeting area. $5 \%$ is a team working room. Only $2 \%$ of all working area appears as individual or personal office.

\subsection{Short-term and very short-term rentable area}

In addition, as indicated by all relevant respondents, short-term rentable and very shortterm rentable areas are not available for any type of working area in head-offices of SLAs.

\subsection{Percentage of relocation type in local authority's head-office}

As indicated by OGC and IPD (2005b), there are four different relocation types as below:

Briefcase - only personal effects, storage with perhaps some telephone / IT equipment;
Briefcase $+I T$ - personal effects, storage, telephone, IT, equipment but not including furniture;

Briefcase $+I T+F u r n i t u r e$ - personal effects, storage, telephone, IT and most furniture/equipment;

Refurbish+Construction - personal effects, storage, telephone, IT, new walls/partitions, new aditional wiring or communication systems and furniture/equipment.

The current survey collected data to compare the proportion of relocation types between traditional layout and modern layout offices. According to the traditional layout office, approximately $3 \%$ of staff relocation is of the briefcase type, $40 \%$ of staff relocated by Briefcase+IT, $41 \%$ of staff relocated as a Briefcase+IT+Furniture type and $15 \%$ of staff relocation is a Refurbish+Construction type. Nonetheless, in the modern layout office, there is only one type of relocation, which is briefcase relocation. The briefcase relocation means staff are able to relocate by moving only his/ her personal effects but not ICT equipment and furniture. This is likely to reflect the lowest relocation cost. This information is used in the analysis section for providing implications regarding the workspace arrangement of both office types. 


\section{DATA ANALYSIS}

\subsection{Working area occupation}

As shown in Figure 6, SLA's officers spend their typical week in many different areas, including individual working area, open-plan area, team working room, informal meeting room, formal meeting room, and outside office.

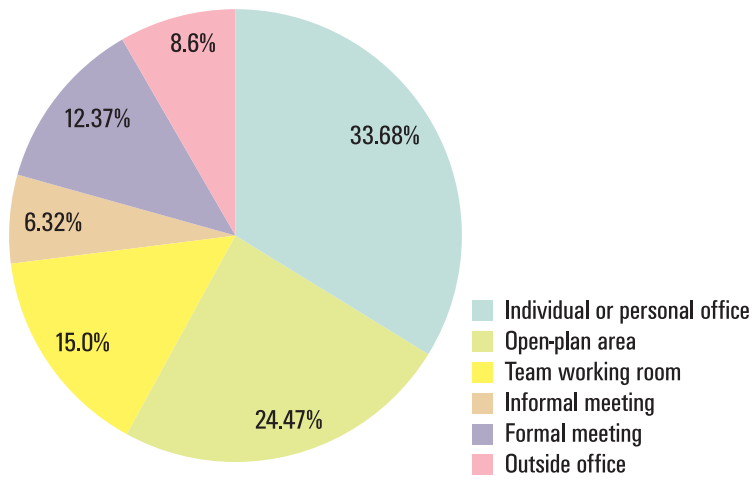

Figure 6. Time spending in different working area
To find out whether this is representative for all management areas, a statistical analysis of the above data has been undertaken. Since the data is not normally distributed the Kruskal Wallis Test was used for testing this non-parametric data (Field, 2005; Black, 1994). As shown in Table 3, the data of time spent in different areas was ranked and the mean rank of each group was calculated (Property, ICT, and HR).

After that, the data of each working area was calculated its sum of ranks, based on the Chi-Square distribution. The sum of ranks, H, can be calculated from:

$$
H=\frac{12}{N(N+1)} \sum_{i=1}^{k} \frac{R_{i}^{2}}{n_{i}}-3(N+1)
$$

where: $N$ is the total sample size; $n$ is the sample size of a particular group; $R_{i}$ is the sum of ranks of each group, and $k$ is the number of group.

Table 3. Mean rank for Kruskal Wallis test of working-time spent in different areas

\begin{tabular}{llll}
\hline Working area & Management area & $\mathrm{N}$ & Mean Rank \\
\hline Individual or personal office & Property/Asset/Estate & 5 & 9.8 \\
& Information \& Communication Technology & 8 & 9.5 \\
& Human Resource & 6 & 10.7 \\
open-plan area & Property/Asset/Estate & 5 & 10.8 \\
& Information \& Communication Technology & 8 & 9.7 \\
& Human Resource & 6 & 9.6 \\
informal meeting & Property/Asset/Estate & 5 & 11.1 \\
& Information \& Communication Technology & 8 & 9.31 \\
formal meeting & Human Resource & 6 & 10.0 \\
& Property/Asset/Estate & 5 & 9.1 \\
team working room & Information \& Communication Technology & 8 & 11.6 \\
& Human Resource & 6 & 8.5 \\
& Property/Asset/Estate & 5 & 12.1 \\
outside office & Information \& Communication Technology & 8 & 8.1 \\
& Human Resource & 6 & 10.8 \\
& Property/Asset/Estate & 5 & 7.5 \\
& Information \& Communication Technology & 8 & 12.8 \\
& Human Resource & 6 & 8.2 \\
\hline
\end{tabular}


Table 4. Kruskal Wallis test of working-time spending

\begin{tabular}{|c|c|c|c|c|c|c|}
\hline \multirow[t]{3}{*}{ Test Statistics (b, c) } & \multirow{3}{*}{$\begin{array}{l}\text { Chi-Square } \\
{[\mathrm{H}]}\end{array}$} & \multirow[t]{3}{*}{$\mathrm{df}$} & \multirow[t]{3}{*}{ Asymp. Sig. } & \multicolumn{3}{|c|}{ Monte Carlo Sig. } \\
\hline & & & & \multirow[t]{2}{*}{ Sig. } & \multicolumn{2}{|c|}{ 99\% Confidence interval } \\
\hline & & & & & Lower bound & Upper bound \\
\hline Individual or personal office & 0.18 & 2 & 0.92 & $.92(\mathrm{a})$ & 0.91 & 0.93 \\
\hline open-plan area & 0.17 & 2 & 0.92 & $.92(a)$ & 0.92 & 0.93 \\
\hline informal meeting & 0.36 & 2 & 0.84 & $.83(\mathrm{a})$ & 0.82 & 0.84 \\
\hline formal meeting & 1.44 & 2 & 0.49 & $.50(a)$ & 0.49 & 0.52 \\
\hline team working room & 1.93 & 2 & 0.38 & $.39(\mathrm{a})$ & 0.38 & 0.40 \\
\hline outside office & 3.93 & 2 & 0.14 & $.14(\mathrm{a})$ & 0.13 & 0.15 \\
\hline
\end{tabular}

(a) Based on 10000 sampled tables with starting seed 126474071

(b) Kruskal Wallis Test

(c) Grouping Variable: Management Area

As shown in Table 4, the sum of ranks $(\mathrm{H})$ of each working area can be displayed in the 'Chi-Square' column. Each H value was used to evaluate its significance of mean comparison. Where degree of freedom (df) is 2 , the asymptotic significant value of time spent in each area is more than 0.05 as well as the significant value estimated by Monte Carlo simulation. Since the analysis shows that there is no significant difference of means amongst property, ICT, and HR management areas, the proportion of time-spent presented in the pie chart above can be representative for the different management areas.

The proportion from the pie chart can be implied that about $25 \%$ of the typical working week of respondents is spent in meeting and outside office activities. This means respondents' desks or workstations are not being occupied during these activities. Consequently, there may be an opportunity to manage the temporarily unoccupied area more efficiently. For example, in one typical week, four staff desks/workstations may have a total 36-hour idle time (or one working day approximately). Theoretically, this may reflect an opportunity to bring in another member of staff to share the desks on condition that the person adopts a suitable flexible-working time scheme. Therefore, the maximum desk allocation, based on the current survey results, is about 1 desk per 1.25 people (i.e. one member of staff $+25 \%$ of a second member of staff's time).

\subsection{Performance benchmarking for flexible working}

The benchmarking data is important to monitor and manage three office resources, which are workspace, ICT and HR (NAO, 2006a). Lacking this data may lead to vague property and financial information causing poor management decision-making (AC, 1988a,b; AC, 2000). According to organisations successfully adopting flexible working, important performance benchmarking data includes annual occupancy cost per area (£/sq.m.), annual occupancy cost per workstation (£/workstation), density area per full-time equivalent (sq.m./ FTE), density area per workstation (sq.m./ workstation), churn cost (Relocation cost $-£)$, and staff satisfaction (\% satisfied staff) (NAO, 2006a,b; IPD, 2005a,b).

According to the current survey, respondents cannot provide most of this performance data because the data may not be collected 
or prepared in their performance records like Property Performance Indicators (PPIs) in Asset Management Plan. Therefore, any SLAs aiming to take-up flexible working need to collect this information in the future to enable them to manage their office resources more flexibly and effectively.

\subsection{Combination of workspace-flexibility concept in practice}

As stated in the literature review, there is an opportunity to include flexibility into each workspace type. Workspace management concepts aim to provide a suitable workspace proportion based on staff activity (Laing et al., 1998; Ward and Holtham, 2000). Portfolio flexibility aims to arrange the suitable workspace proportion based on organisational business needs (Gibson and Lizieri, 1999; Gibson and Lizieri, 2000; Gibson, 2000).

Based on the survey results indicated in Section 4.3, Figure 7 presents the proportion of workspace type of traditional layout SLA offices. According to relocation in the traditional layout office mentioned in the section 4.5, it can be implied that arranging people to the wrong workspace type may affect, for example, high churn rate and cost, low staff satisfaction, and ineffective resource management (NAO, 2006a; Gibson and Luck 2004; Szarejko and Trocka-Leszczynska, 2007). According to Laing et al. (1998) and Ward and Holtham (2000), because various churn types occur in this building type, this means that the current workspace proportion may not reflect a proportion of staff activity.

According to the survey results indicated in Section 4.4, Figure 8 presents portfolio flexibility of SLA's offices. Clearly, portfolio flexibility of workspace in both short-term and very short-term does not appear in any SLA. As commented by SLA staff, restrictions of legislation, regulation, and working culture in SLA may be barriers against adoption of the model at present.

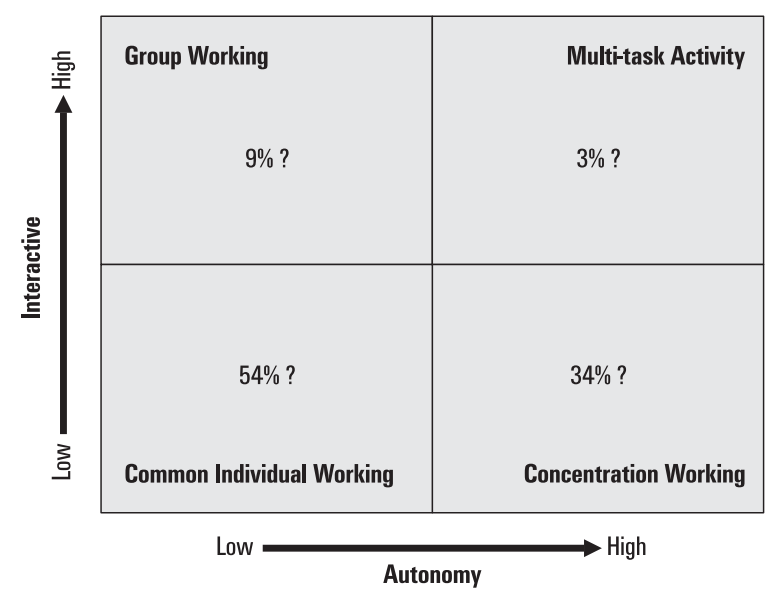

Figure 7. Proportion of activity based working area in traditional layout SLA offices

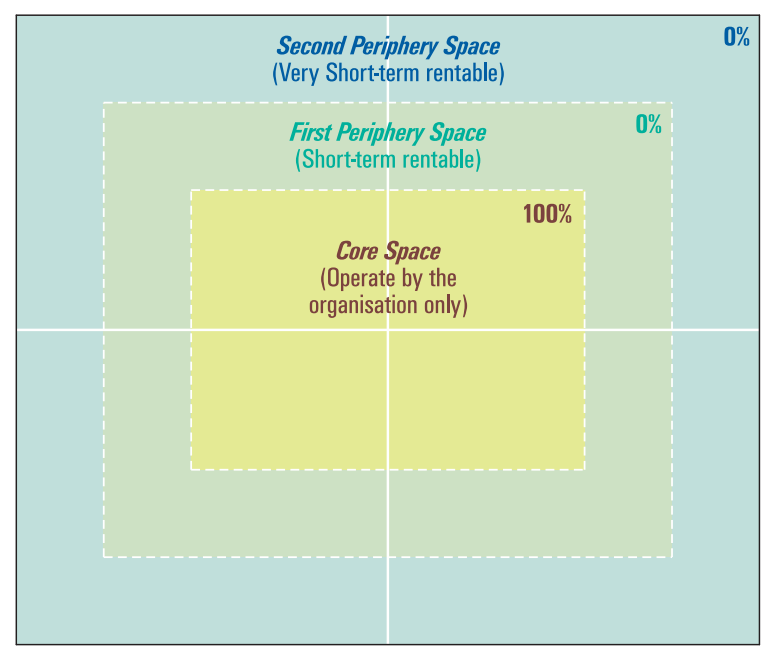

Figure 8. Portfolio flexibility of traditional layout offices

\section{DISCUSSION}

\subsection{Combined resource management}

The analysis shows that, in the context of SLAs, portfolio flexibility, especially short- and very shot-term rentable areas is not adopted at present. Therefore, to manage the SLA office resources better, the original models, which are portfolio flexibility and workspace models, should be adapted to be used in the SLA context. 


\subsubsection{Adapted portfolio flexibility model}

The original concept of the portfolio flexibility model proposed by Gibson and Lizieri (1999) cannot be used to effectively explain the current working practice of SLAs. The current survey results show that none of the SLAs apply this concept to its office management practice. Arguably, trying to introduce SLAs to share or let some office area may not be warmly welcomed. Consequently, the original model should be adapted to use with an organisation which intends to occupy its office space individually. An adapted portfolio flexibility model is presented in Figure 9.

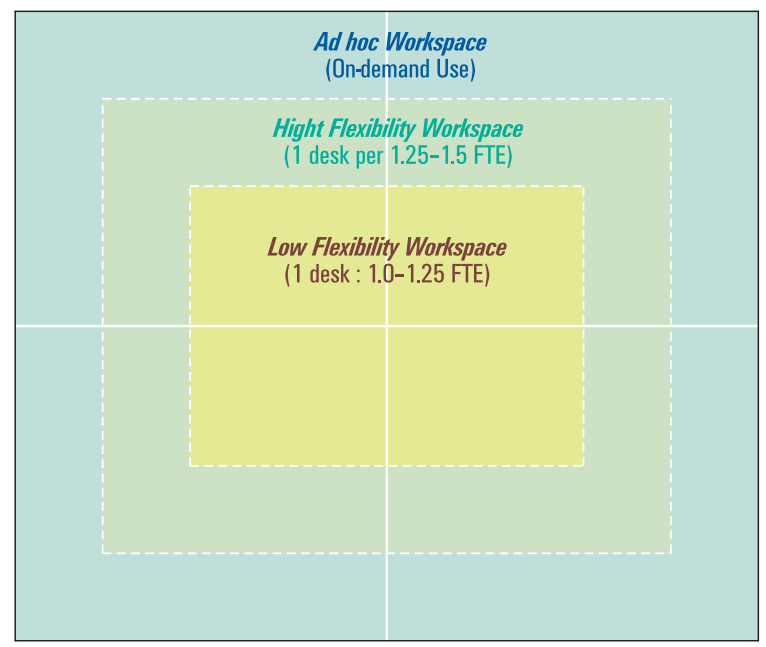

Figure 9. Adapted portfolio flexibility model

The model contains three levels of flexibility, which are:

\section{Low flexibility workspace}

According to the OGC and IPD (2005a,b), the desk allocation ratio of public offices should not exceed 1 desk per 1 person. This means that a member of staff should not own two or more working desks/workstations in the organisation office at the same time. Moreover, as described in the analysis in Section 5.1, the current research suggests a desk allocation ra- tio of 1 desk: 1.25 FTE (4 desks per 5 people, based on full-time equivalent calculation) may be used as the maximum desk allocation ratio in the lowest flexibility workspace area. Staff who are suitable to work in this area should, ideally, spend time at their desks at least 75\% of their typical week. Where suitable staff can be arranged to work in this area, therefore, a higher degree of occupational efficiency is likely to be achieved.

Consequently, because this area is always occupied by staff, facilities services (e.g. electrical, air-conditional, and heat) can be fully provided during the normal working time. For ICT services, an organisation can provide mainly fixed-line-access services, such as fixed workstation, wired telephone, and Voice over Internet Protocol (VoIP).

\section{High flexibility workspace}

This type of workspace should be assigned to staff spending his/her time in the office area less than $75 \%$ of their typical week. In addition, this area may be assigned to parttime staff working on various contracts and working schemes. In general, part-time staff, having their working hours around a half of the typical working week of full-time staff, may spend their time in the office only $50 \%$ of general staff. As a result, the maximum desk allocation ratio of this area can be calculated on the condition that all staff in this area spend $50 \%$ of the typical working week. Therefore, the maximum desk allocation ratio or this workspace area can be 1 desk: $1.5 \mathrm{FTE}$ ( 2 desks per 3 people, based on full-time equivalent calculation).

According to the high flexibility of desk occupation in this workspace, staff may work in different locations throughout this workspace area. At any particular time, there may be a group of unoccupied desks. Therefore, the facility services should be operated on the basis of flexible service. For example, lighting and electrical supply may be able to automatically 
turn on when some part of this area is occupied. Since staff working in this area need to independently and flexibly share desks/workstations, ICT support services, such as wireless LAN, and wireless devices, should be adequately provided to this area.

\section{Ad hoc workspace}

This workspace area suits staff spending less than $50 \%$ of their typical week in the office. Desk allocation ratio for this workspace area is more than 1 desk: 1.5 FTE. Moreover, facility services can be provided on an ad hoc or on-demand basis. From an operational efficiency point of view, ICT support services should be mainly wireless network and a limited number of fixed-line-access services.

\subsubsection{Adapted workspace model for ICT}

According to the workspace models proposed by Laing et al. (1998) and Ward and Holtham (2000), some ICT provisions can be added to the model to allocate suitable ICT services in each workspace as below (Figure 10) (Gibson and Luck, 2004):

\section{Common individual working area}

Staff working in an open-plan working area should be provided mainly fixed-line-access ICT services, such as local intranet and

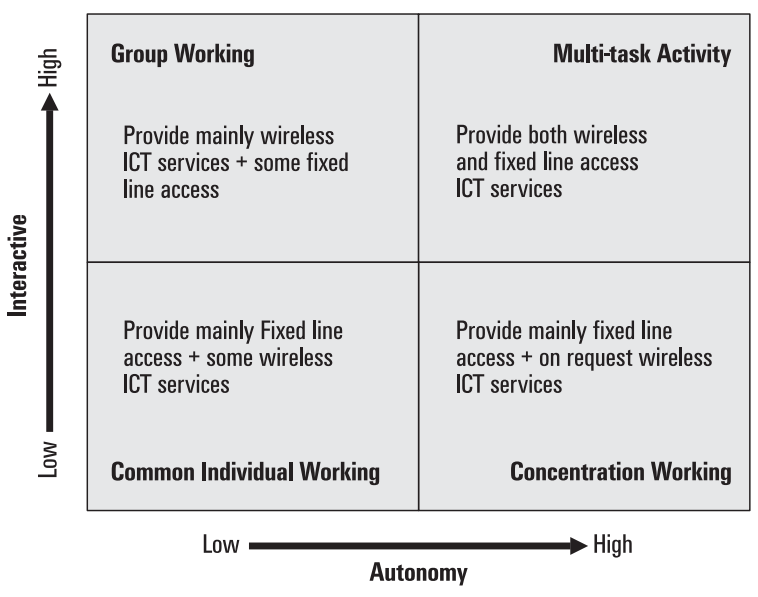

Figure 10. Adapted workspace model for ICT internet access, and some wireless ICT services for some flexible works. Standardisation of ICT applications, particularly hardware and software, should be completely implemented across this area to support the lowest cost of relocation.

\section{Concentration working area}

This area can be seen as closed room layout. Main ICT services should be a fixed-lineaccess type, such as individual workstation/ PC. Standardisation of ICT is needed to a normal level because it may not assist in reducing relocation costs within this area. Additional ICT services may be provided on request for particular users.

\section{Group working area}

Formal and informal meeting rooms are included in this area. This area is a public area and may be used by anyone in the organisation. Therefore, ICT services should be provided on high flexibility basis. Wireless network and wireless devices are useful for assisting staff working in this area. However, some fixed-line-access services, such as cable connection, can be implemented for a particular circumstance.

\section{Multi-task working area}

To support activities in this workspace area, specific ICT equipment, such as large screen monitors and Computer Aided Design tools, may be implemented to support expertise. Standardisation of ICT equipment may not be required for this working area.

\subsubsection{Adapted workspace model for workspace management}

According to the workspace models proposed by Laing et al. (1998) and Ward and Holtham (2000), some workspace management provisions can be added to the model to introduce workspace management policy in each workspace as below (Figure 11) (Gibson and Luck, 2004; Harris, 1996): 


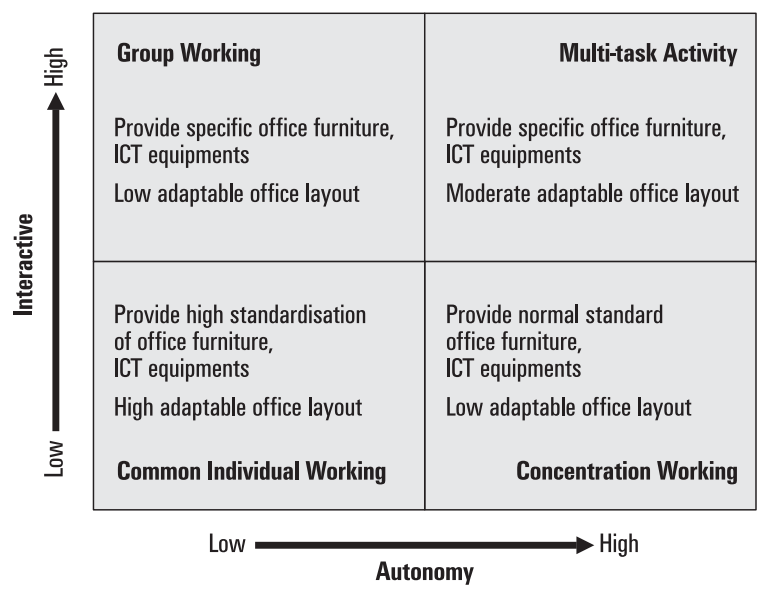

Figure 11. Adapted workspace model for workspace management

\section{Common individual working area}

Staff working in an open-plan working area should be provided with a high standardisation of office furniture and ICT equipment to support the lowest cost of relocation. Moreover, office layout in this area should be easily adapted to support the future organisation business needs.

\section{Concentration working area}

High standardisation of office furniture and equipment may not be necessary for individual/personal working area because any relocation within or from this area may have some furniture/equipment movement costs. Moreover, in particular cases, refurbishment or construction cost may arise when staff have a major relocation.

\section{Group working area}

Formal and informal meeting rooms are temporarily used for specific purposes, such as meetings and presentations. Furniture and office equipment are usually different from the normal working area. An office layout of this area may not be easily adapted. Therefore, standardization of furniture is needed to adapt an office layout within this area.

\section{Multi-task working area}

Although the team working area contains specific ICT equipment and office furniture, this area is usually an open-plan working area for a small working group. Some standardisation of office furniture provided in this area is required to support relocation.

\subsubsection{Combined resources management strategy}

The adapted models proposed above are aimed at use in office resource management. As addressed in the literature review, flexible working benefits an individual to work more effectively. It also benefits an organisation to manage its office more effectively. However, the major barrier for adopting flexible working is budget constraint. This section aims to propose a model interpreting flexible working adoption in practice to financial and economic terms. This model may assist an organisation to have a financial/economic perspective of its flexible working practice before taking-up. As shown in Figure 12, there are five stages of a combined resource management strategy.

Each stage is described as below:

\section{STAGE I}

Staff in an organisation should be provided adequate flexible working support. For HR policy, staff must be able to apply any flexible working contract (e.g. job-sharing, V-time, and term-time contracts) and flexible working scheme (e.g. flexitime, compressed hours, annualised hours, and self-rostering). ICT services for alternative workplaces, such as satellite, home, guest and instant offices, should be provided to an adequate level.

\section{STAGE II}

Proportion of staff working hours between office premises (e.g. head-office and satellite office) and alternative workplaces (e.g. home, instant office) should be established to use for allocating a suitable proportion amongst various activity-based workspaces. 


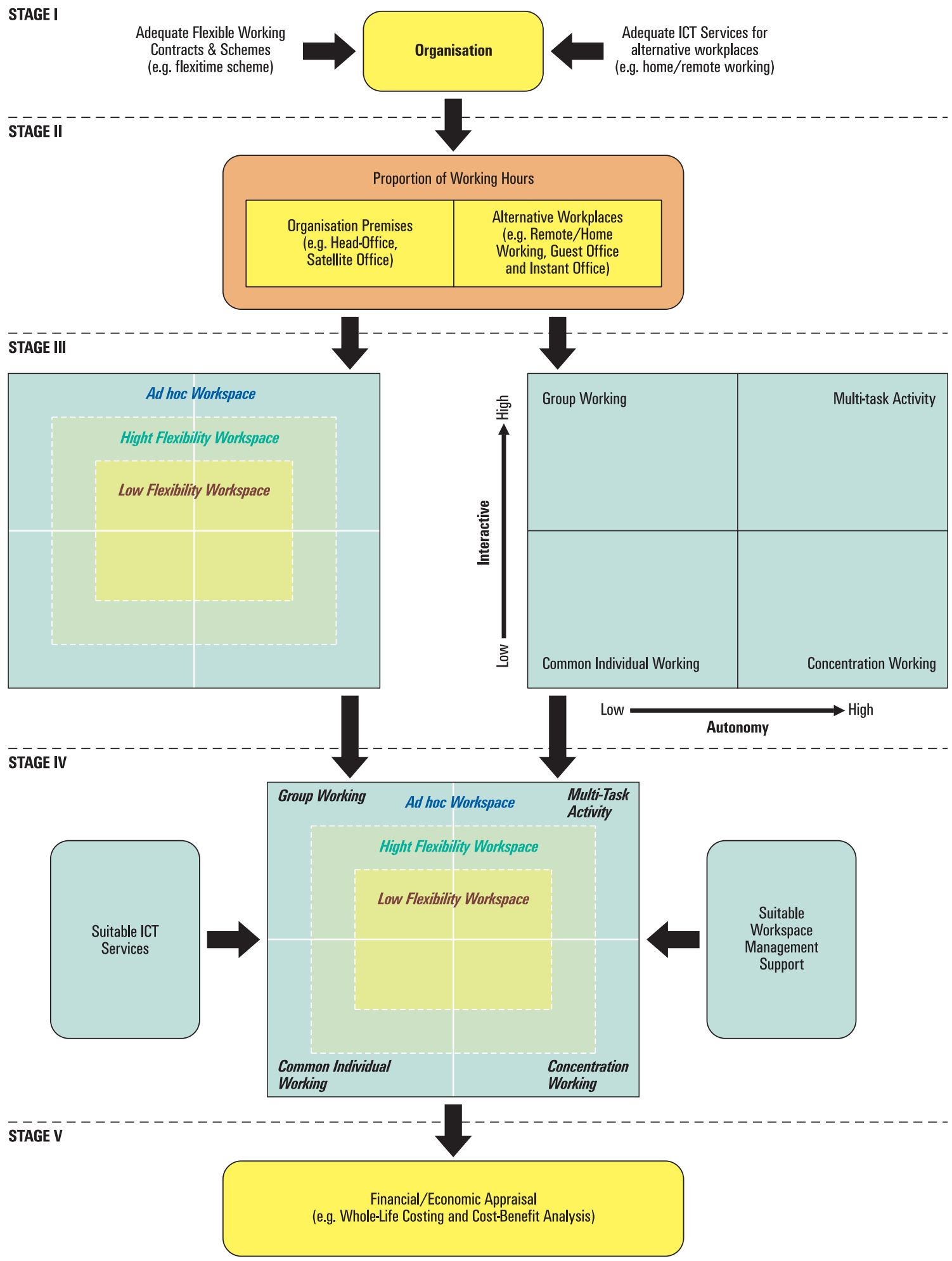

Figure 12. Combined resource management strategy 


\section{STAGE III}

Working area should be arranged for staff on the basis of two concepts. First, the adapted portfolio flexibility model can be used to arrange staff based on time spent in the office. Second, the activity-based workspace model is used to categorise staff into four work activity areas, which are individual, open-plan, group, and multi-task working areas.

\section{STAGE IV}

The proportions from the two models above have to be merged to a single model containing the proportion of staff in activity-based working area and flexibility level. The new proportion is expected to be used for allocating suitable ICT services (e.g. fixed line services and wireless network) and suitable workspace management support (e.g. standardisation of office furniture and ICT equipment) to any activity-based workspace. The proportion is also used to review and adjust the current office layout based on the actual proportion of working area needs.

\section{STAGE V}

Short-term and long-term financial/economic appraisal of adopting flexible working can be analysed by, for example, Whole-Life Costing approach or Cost-Benefit Analysis. For instance, costs of flexible working implementation can be calculated from the cost of new office equipment and furniture, refurbishment and construction work. Tangible benefits can be evaluated from potential cost savings, including facility service, travel, operational and maintenance costs. Intangible benefits include the higher degree of staff satisfaction, stress reduction, etc.

The combined resource management strategy is proposed to assist SLAs to overcome a problem of budget constraint when trying to take-up flexible working. The main reason is that flexible working does not only affect HR, but also ICT and workspace management (Gib- son and Luck, 2004; NAO, 2006a). To evaluate realistically, all costs and benefits occurring from the three components must be reviewed and analysed.

\section{CONCLUSIONS}

An opportunity to manage working area more tightly has been stated in UK Government reports and research, where the concept of flexible working is proposed. Where staff can work more flexibly, office resources, especially ICT and workspace, should also be managed more efficiently. In general, a proportion between unoccupied and occupied workspace can be used to increase density of desk allocation in an office. As the current results show, the ratio, 1 desk: $1.25 \mathrm{FTE}$, is possible to adopt in the context of SLA.

As stated in previous research, an inappropriate proportion of workspace may lead to costly relocation, such as high ICT equipment, furniture, and refurbishment/construction. Promoting of activity-based workspace in public offices, like SLA, can be of benefit, in terms of churn cost saving. According to the current survey results, promoting open-plan as a major working area in the modern layout buildings shows the lowest-cost of relocation. However, the traditional layout buildings, having a large area of cellular office, have various costly churn types. This may reflect an inappropriate working area allocation in the current practice.

To manage office areas more strategically, benchmarking data relating flexible working should be regularly prepared, collected, and monitored. Theoretically, previous Government reports and research indicate that the performance benchmarks are important for managing a flexible working environment. An organisation aiming to adopt flexible working should begin to seriously prepare and maintain such data. 
Employing the principles of commercial workspace management to the public offices may not be always applicable in practice. Portfolio flexibility providing multi-levels of utilisation is not being promoted in SLAs at present. This may imply some restrictions of public organisation, in terms of regulation, legislation, and working culture. To assist the public offices like SLAs in taking-up of flexible working more effectively, the models of current commercial workspace management concept should be adapted. The proposed option is a combined resource management strategy. The concept is based on the current survey results and the workspace/portfolio flexibility models. The combined resource management of three components, ICT, HR, and workspace management, may lead SLAs to gain a clearer picture of flexible working in practice. The model also creates an opportunity to evaluate flexible working strategy in financial and economics terms for both short- and long-term implementation periods.

There is evidence from the current research to confirm that flexible working can be a tool for managing office resource. Promoting the right activity-based working area and appropriate workspace flexibility to the property may help an organisation to achieve the successful adoption of flexible working. Beside, the flexible working concept can assist both the individual and the organisation to achieve benefits, including balancing work and family life and effective resource management.

\section{LIMITATIONS AND RECOMMENDATIONS}

As a result of a limited sample size, the research results must be treated with some caution. However, even though based on a small sample size, the outcomes do provide some valid insights into the characteristics of SLAs and their attitudes to adoption of flexible working practices. Although it is not possible to gen- eralise the results to other types of organisations, the research insights may be tentatively applied to a particular organisation if it has similar characteristics to the SLA sample.

Key implications on financial and economic perspectives of flexible working adoption are unable to be investigated at this stage because the benchmarking information relating to flexible working is rarely prepared and provided by the staff of SLAs. Although previous research may state that flexible working benefits an organisation to achieve more effective resource management, no evidence in the current research confirms that the higher flexible working stage always provide the lower total cost of implementation. Therefore, a crucial task for future research is to investigate the relationship of the flexible working stage and performance benchmarks. The relationship will provide important investment information to senior management for making the take-up decision. In addition, financial and economic appraisal of flexible working should be reviewed before taking-up in practice. To achieve this, some methods, such as Whole-Life Costing or Cost Benefit Analysis, could be employed to investigate this proposal. The possible outcomes may also include Value for Money (VFM) of flexible working in each evaluation stage.

\section{REFERENCES}

Audit Commission (1988a) Local Authority Property: A Management Overview. London: HMSO.

Audit Commission (1988b) Local Authority Property: A Management Handbook. London: HMSO.

Audit Commission (2000) Hot Property: Getting the best from local authority assets. London: the Audit Commission for Local Authorities and the National Health Service in England and Wales.

Black, K. (1994) Business Statistics: Contemporary Decision Making. New York: West Publishing.

Bryman, A. (2004) Social Research Methods. $2^{\text {nd }}$ ed. New York: Oxford University Press. 
Dawson, C. (2006) A Practical Guide to Research Methods: A user-friendly manual for mastering research techniques and projects. $2^{\text {nd }}$ ed. Oxford: How to Books.

Dettwiler, P. (2008) Modelling the relationship between business cycles and office location: The growth firms, Facilities, 26(3/4), pp. 157-172.

DfEE (2000) Work-life balance: Changing Patterns in a changing world. London: Department for Education and Employment.

Dillman, D. A., Eltinge, J.L., Groves, R.M. and Little, R.J.A. (2002) Survey Nonresponses in design, data collection, and analysis. In: Groves, R.M., Dillman, D.A., Eltinge, J.L. and Little, R.J.A. (eds.) Survey Nonresponse. New York: John Wiley \& Sons.

Dillman, D.A. (2000) Mail and Internet Surveys: The tailored design method. $2^{\text {nd }}$ ed. New York: Wiley.

Field, A. (2005) Discovering Statistics: Using SPSS. $2^{\text {nd }}$ ed. London: SAGE.

Fink, A. (2006) How to conduct surveys: A step-bystep guide. $3^{\text {rd }}$ ed. London: SAGE

Gershon, P., Sir (2004) Releasing resources to the front line: Independent Review of Public Sector Efficiency. London: HMSO.

Gibson, V. (2000) Property portfolio dynamics: thee flexible management of inflexible assets, $F a$ cilities, 18(3/4), pp. 150-154.

Gibson, V. (2003) Flexible working needs flexible space?: Towards an alternative workplace strategy, Journal of Property Investment and Finance, 21(1), pp. 12-22.

Gibson, V. and Hedley, C. (1999) Information and Performance Measurement: A Study of Current Practice in Corporate Property Management. The Cutting Edge 1999: Proceedings of the RICS Research Conference, Cambridge, $6^{\text {th }}$. $7^{\text {th }}$ September 1999. Cambridge: Cambridge University.

Gibson, V. and Lizieri, C. (1999) New business practices and the corporate real estate portfolio: How responsive is the UK property market? Journal of Property Research, 16(3), pp. 201-218.

Gibson, V. and Lizieri, C. (2000) Change and flexibility: The role of serviced office space in office markets and corporate property portfolios, RICS Research Papers, 3(12), pp. 1-16.
Gibson, V. and Luck, R. (2004) Flexible working in Central Government: Leverage the benefit. London: Office of Government Commerce.

Harris, R. (1996) Less a Castle, More a Condominium: Taking a look at the office of the future. London: Gerald Eve Research.

Laing, A. Duffy, F., Jaunzens, D. and Wills, S. (1998) New Environments for Working: The Redesign of Offices and Environmental Systems for New Ways for Working. London: E\&FN Spon.

Lyons, M., Sir (2004a) Well Placed to Deliver? Shaping the Pattern of Government Service. London: HMSO.

Lyons, M., Sir (2004b) Towards Better Management of Public Sector Assets: A Report to the Chancellor of the Exchequer. London: HMSO.

McGregor, W. (2000) The future of workspace management, Facilities, 18(3/4), pp. 138-143.

NAO (2006a) Getting the best from public sector office accommodation. London: National Audit Office Press Office.

NAO (2006b) Getting the best from public sector office accommodation: case study. London: National Audit Office Press Office.

Nenonen, S. (2004) Analysis the intangible benefits of work space, Facilities, 22(9/10), pp. 233-239.

OGC (2006) Better Measurement Better Performance. London: OGC.

OGC and IPD (2005a) Property Benchmarking Project OGC/51 - Final Report for Pilot Phase. London: OGC and IPD.

OGC and IPD (2005b) Property Benchmarking Project OGC/51 - Final Report for Pilot Phase: Appendices. London: OGC and IPD.

Simms, C. and Rogers, B. (2006) The significance of flexibility in improving return on property investment: The UK perspective, Facilities, 24(3/4), pp. 106-119.

Szarejko, W. and Trocka-Leszczynska, E. (2007) Aspect of functionality in modernization of office buildings, Facilities, 25(3/4), pp. 163-170.

Ward, V. and Holtman, C. (2000) The role of private and public spaces in knowledge management. Proceedings of the BPRC Conference on Knowledge Management: Concepts and Controversies, 10-11 February 2000. Coventry: Warwick University. 


\section{SANTRAUKA}

\section{LANKSTUS DARBAS ŠKOTIJOS VIETOS VALDŽIOS POŽIŪRIU: KURIAME KOMBINUOTĄ IŠTEKLIŲ VADYBOS STRATEGIJĄ}

\section{Thadsin KHAMKANYA, Brian SLOAN}

Kaip rodo Vyriausybès ataskaitos ir ankstesnis tyrimas, ir centrinès, ir vietos valdžios tradiciniuose biuruose daug dėmesio skirta didelèms turto valdymo sąnaudoms. Lankstus grafikas, pagrịstas informacinių ir komunikaciniu technologijų, žmogiškujų ištekliu ir darbo vietos vadyba, atsirado kaip modernus biuro išteklių valdymo būdas. Jau yra darbo vietos valdymo modelių, kurie apima ir su veikla susijusią darbo vieta, ir portfelio lankstuma, leidžia organizacijai lanksčiau ir efektyviau paskirstyti darbuotojus bei biuru plota. Tačiau mažai tikètina, kad valstybinès organizacijos, pavyzdžiui, Škotijos vietos valdžia, perims nepakeistus komercinius darbo vietos valdymo modelius. Todèl pristatyta kombinuotos ištekliu vadybos strategijos idèja, kuri padètų valdžiai apsvarstyti modeliu taikymą finansine ir ekonomine prasme prieš realiai imantis lankstaus darbo. 